\title{
Use of different organic fertilizers on soil fertility improvement, growth and head yield parameters of cabbage (Brassica oleraceae $\mathrm{L}$ )
}

\author{
Emmanuel Ibukunoluwa Moyin-Jesu'
}

Received: 10 February 2015/ Accepted: 6 October 2015/Published online: 9 November 2015

(c) The Author(s) 2015. This article is published with open access at Springerlink.com

\begin{abstract}
Purpose Field experiment was carried out in Akure in the rainforest zone of Nigeria to determine the effect of poultry manure, wood ash and rice bran on the soil fertility improvement, growth and head yield of cabbage (Brassica oleraceae L) in 2011 and 2012 cropping seasons.

Methods The three organic fertilizer treatments were applied each at $6 \mathrm{t} / \mathrm{ha}$ with a reference treatment NPK 15-15-15 applied at $300 \mathrm{~kg} / \mathrm{ha}$ and a control treatment arranged in a randomized complete block design with three replicates.

Results The results showed significant increases $(P<0.05)$ in the growth and head yield parameters of cabbage crop under the different organic fertilizers compared to the control treatment. The application of poultry manure resulted in the highest values of cabbage plant height, stem girth, leaf number, leaf area, head weight, head length and head girth followed by NPK 15-15-15, wood ash and rice bran, respectively. Cabbage head weight, head girth, head length, plant height, stem girth, leaf number and leaf area increased by 17, 18, 8,17, 19, 10 and $16 \%$, respectively, with application of poultry manure compared to NPK fertilizer. Also, these parameters increased by $23,21,1329,25,17$ and $45 \%$ compared to the wood ash treatment. The highest values of soil $\mathrm{pH}, \mathrm{Ca}$ and $\mathrm{Mg}$ were obtained under wood ash application, while the highest values of soil O.M and moderate values of soil $\mathrm{P}, \mathrm{K}, \mathrm{Ca}$ and $\mathrm{Mg}$ were obtained under poultry manure application. Moderate values of soil $\mathrm{pH}, \mathrm{K}, \mathrm{Ca}$ and low \%
\end{abstract}

Emmanuel Ibukunoluwa Moyin-Jesu

moyinjesu2004@yahoo.com

1 Agronomy Department, Federal College of Agriculture, Akure, Ondo, Nigeria
$\mathrm{N}$ were also recorded under rice bran treatment. However, the highest $\mathrm{K} / \mathrm{Ca}, \mathrm{K} / \mathrm{Mg}$ and $\mathrm{P} / \mathrm{Mg}$ ratios of $93.1,74.1$ and 572.1, respectively, were obtained under NPK 15-15-15 fertilizer application compared to $2: 1 \mathrm{~K} / \mathrm{Ca}, 2: 1 \mathrm{~K} / \mathrm{Mg}$ and $16: 1 \mathrm{P} / \mathrm{Mg}$ in rice bran treatment.

Conclusion The poultry manure applied at $6 \mathrm{t} / \mathrm{ha}$ gave the best results in improving soil fertility, growth and head yield of cabbage, and this was because of its balanced nutrient composition and the least $\mathrm{C} / \mathrm{N}$ ratio.

Keywords Cabbage (Brassica oleraceae) · Head yield and growth parameters - Organic fertilizers and soil fertility improvement

\section{Introduction}

Cabbage is a leafy vegetable belonging to the Brassicaceae family which is originated from California. Hague (2006) cabbage is also an herbaceous biennial plant that produces "heads", and it has short stem upon which is crowned with a mass of green leaves (John 1997).

Cabbage is consumed raw or cooked with other vegetables; it contains $93 \mathrm{ml}$ water, $15 \mathrm{~g}$ protein, $0.2 \mathrm{~g}$ fat, $4.0 \mathrm{~g}$ carbohydrate, $4 \mathrm{~g}$ calcium and $0.5 \mathrm{~g}$ iron $/ 100 \mathrm{~g}$ sample (Moamogwe 1995). In addition, it has high medicinal value because of its rich content in vitamins $\mathrm{C}, \mathrm{E}$ and $\mathrm{K}$ as well as its antioxidant components which suppressed cancerous cell growth (Tindall 2000). It is one important vegetable in healthy diets of people around the world.

In spite of the economic, nutritional and health importance of cabbage to the national development, its optimum production has not been achieved due to its difficult agronomic characteristics, decline in soil fertility, lack of 
techniques of growing the crop in both the nursery and field. However, efforts made to increase the soil fertility through the use of inorganic fertilizers are limited due to high cost of purchase and continuous use which destroyed soil properties (Moyin-Jesu 2008).

Besides, the climatic condition for growing cabbage in temperate region is between 20 and $25{ }^{\circ} \mathrm{C}$ and adaptation of the crop to Nigeria, especially south-west, is difficult because temperature is between 29 and $37{ }^{\circ} \mathrm{C}$. In other parts of the country (Northern region), the temperature ranged between 36 and $41{ }^{\circ} \mathrm{C}$ except the Jos Plateau where temperature is about $24-27^{\circ} \mathrm{C}$.

Therefore, there is justification to adapt the cultivation of cabbage to the climatic condition in Nigeria, especially in south-west, as well as adopting the use of low-cost organic fertilizers for the crop cultivation. Kwari et al. (1991) found that the incorporation of grass cow dung into the soils in Borno state improved the cation exchange capacity of the soils. Solomon and Ogeh (1995) indicated that leguminous materials and rice husk supplied mainly $\mathrm{N}$, $\mathrm{P}, \mathrm{K}, \mathrm{Zn}, \mathrm{Fe}, \mathrm{Cu}, \mathrm{Mn}$ and $\mathrm{B}$ to the soil which NPK 15-1515 fertilizer did not possess.

Ojeniyi et al. (2001) also reported that application of wood ash to the vegetable crops improved the yield of crops significantly and increased the soil nutrients such as $\mathrm{N}, \mathrm{P}, \mathrm{K}, \mathrm{Ca}, \mathrm{Mg}$ in a trial conducted in south-west Nigeria. Awodun (2007) also reported that sawdust applied to soil significantly increased soil and leaf $\mathrm{N}, \mathrm{P}, \mathrm{K} \mathrm{Ca}$ and $\mathrm{Mg}$ contents and number of pods, pod weight, number of branches, number of leaves and grain yield of cowpea.

Moyin-Jesu (2013a) reported that the modified neem extracts (neem leaf + wood ash extracts) increased significantly the garden egg fruit weight, fruit length and fruit diameter by 42,24 and $13 \%$ compared to NPK 15-15-15 fertilizer. He also observed that continuous application of NPK 15-15-15 fertilizer decreased soil $\mathrm{pH}, \mathrm{Ca}, \mathrm{Mg}$ and O.M as well as having highest $\mathrm{K} / \mathrm{Ca}, \mathrm{K} / \mathrm{Mg}$ and $\mathrm{P} / \mathrm{Mg}$ ratio caused soil nutrient imbalance.

Moyin-Jesu and Ogochukwu (2014) also reported that poultry manure applied at $6 \mathrm{t} / \mathrm{ha}$ increased the soil $\mathrm{N}, \mathrm{P}, \mathrm{K}$, $\mathrm{Ca}$ and $\mathrm{Mg}$ concentrations and growth parameters of coconut seedlings. He also reported that the organic materials applied (wood ash, rice bran and so firth) have beneficial residual effects on soil properties which are in line with growing concern of using environment friendly fertilizer.

Furthermore, Obi and Ofonduro (1997) and Moyin-Jesu (2007) also reported that problems associated with continuous use of chemical fertilizers included nutrient imbalance, increased soil acidity, degradation in soil physical properties and loss of organic matter. Hence, the tendency to supply all plant nutrients through chemical fertilizer should be reconsidered in the future because of the deleterious effect on soil productivity on a long-term basis.

Finally, Afshar et al. (2014) reported that soil organic amendments improved the seed yield and flavonolignan production of milk thistle (Silyburn marianum L, Gaertin) compared to chemical fertilizers. Critical review of literature revealed that there is scarcity of research report on the use of wood ash, rice bran and poultry manure in growing cabbage except the works of Moyin-Jesu and Odewande (2013b); Ijoyah and Sophie (2009) and Mohammed and Solaiman (2012) working on varietal trial of cabbage and tillage influence on cabbage yield.

The choice of wood ash, rice bran and poultry manure as source of organic materials in the research study was because of their availability and abundance in large quantities from the experimental location and its surrounding communities where majority of the farmers are predominantly cassava, rice growers with associated processing mills and poultry producers. Moyin-Jesu and Ojeniyi (2006) also reported that application of rice bran wood ash and spent grain significantly reduced soil bulk density and increased porosity. Hence, the use of wood ash and rice bran as organic amendments would also have strong beneficial improvement on soil physical properties and base saturation.

\section{Purpose of the experiment}

The following research questions would be answered for the experiment: (1) Is there any significant difference between applied organic fertilizers on growth and head yield parameters of cabbage? (2) Is there any significant difference between the applied organic fertilizers and postcropping soil properties?

The objectives of the research were to determine the effect of wood ash, rice bran and poultry manure on the growth and yield parameters of cabbage and on postcropping soil properties.

\section{Materials and methods}

\section{Description of the study area}

Field and nursery experiments were carried out at Akure in the rainforest zone of Nigeria in 2011 and were repeated in 2012 to validate the results. The soil of the experimental site is loamy sand, skeletal, kaolinitic, isohyperthermic Oxic paleustalf (Alfisol) Soil Survey Staff (1999). The annual rainfall of the area is between 1000 and $2060 \mathrm{~mm}$ and the annual temperature is between $29-37^{\circ} \mathrm{C}$ as presented in Table 1. 
Table 1 Monthly rainfail and temprature data for Akure in 2011 and 2012

\begin{tabular}{|c|c|c|c|c|c|c|}
\hline \multirow[t]{2}{*}{ Months } & \multicolumn{2}{|c|}{ Rainfall (mm) } & \multicolumn{2}{|c|}{ Temperature $\left(0^{\circ} \mathrm{C}\right)$} & \multicolumn{2}{|c|}{$\begin{array}{l}\text { Modified temp. }\left(0^{\circ} \mathrm{C}\right) \text { of the environment under } \\
\text { shade structure during the experiment (March-July) }\end{array}$} \\
\hline & 2011 & 2012 & 2011 & 2012 & 2011 & 2012 \\
\hline January & 1.90 & - & 33.70 & 36.30 & - & - \\
\hline February & 41.10 & 34.80 & 36.10 & 35.60 & - & - \\
\hline March & 127.10 & 40.00 & 35.00 & 37.10 & 22.10 & 22.60 \\
\hline April & 230.00 & 81.80 & 29.10 & 32.20 & 23.10 & 23.40 \\
\hline May & 222.30 & 156.60 & 30.30 & 29.30 & 22.80 & 22.60 \\
\hline June & 162.00 & 195.80 & 32.20 & 31.20 & 22.50 & 22.30 \\
\hline July & 169.00 & 423.00 & 29.10 & 29.20 & 22.30 & 22.00 \\
\hline August & 169.00 & 682.90 & 31.40 & 30.10 & 22.90 & 22.70 \\
\hline September & 378.00 & 240.90 & 30.70 & 32.30 & - & - \\
\hline October & 141.90 & 111.60 & 33.10 & 31.10 & - & - \\
\hline November & 51.30 & 93.20 & 33.60 & 35.30 & - & - \\
\hline December & - & - & 32.70 & 34.60 & - & - \\
\hline
\end{tabular}

Source: meteorological station Federal College of Agriculture, Akure

\section{Pre-cropping soil sampling and analysis}

Thirty core samples were collected from 0 to $15 \mathrm{~cm}$ depth, bulked together, air-dried, sieved with $2 \mathrm{~mm}$ and ready for routine analysis.

The soil $\mathrm{pH}\left(1: 1 \mathrm{soil} /\right.$ water and 1:2 soil/0.01 $\left.\mathrm{M} \mathrm{Cacl}_{2}\right)$ was read on $\mathrm{pH}$ meter (Crockford and Nowel 1956), while organic matter was determined using wet oxidation method through chromic acid digestion (Walkley and Black 1934). Soil P was extracted by Bray P1 extractant, and the extract was developed on Murphy blue colouration and determined on a spectronic 20 (Murphy and Riley 1962).

Soil $\mathrm{K}, \mathrm{Ca}, \mathrm{Mg}$ and $\mathrm{Na}$ were extracted with $1 \mathrm{M} \mathrm{NH}_{4} \mathrm{OAC}$ $\mathrm{pH} 7$, and their contents $\mathrm{K}, \mathrm{Ca}$ and $\mathrm{Na}$ were read on the flame photometer (Jackson 1958), while Mg content was determined using the atomic absorption spectrophotometer.

The soil nitrogen was determined using the micro-Kjeldahl method (Jackson 1964), while the micronutrients (Fe, $\mathrm{Cu}, \mathrm{Zn}$ and $\mathrm{Mn}$ ) were extracted with $0.1 \mathrm{M}, \mathrm{HCl}$ and read on atomic absorption spectrophotometer. Particle size analysis was carried out using hydrometer method (Bouycous 1951).

Table 2 shows the soil chemical composition before planting. The soil P $5.20 \mathrm{mg} / \mathrm{kg}$ is lower than $10 \mathrm{mg} / \mathrm{kg} \mathrm{P}$ recommended for crop production in south-west Nigeria (Agboola and Corey 1973). The organic matter was also below $3 \%$ critical level for crop production (Agboola and Corey 1973).

Soil N content was $0.08 \%$ which is lower than $0.15 \%$ $\mathrm{N}$ critical level for crops recommended by Sobulo and Osiname (1981). The exchangeable bases (K, Ca, Mg and $\mathrm{Na}$ ) were below $0.20 \mathrm{mmol} / \mathrm{kg}$ recommended by Folorunso et al. (2000). The soil pH 5.82 showed that the soil is slightly acidic. The soil textural class is loamy sand.
Table 2 Soil properties before planting

\begin{tabular}{lc}
\hline Soil properties & Values \\
\hline Soil pH $\left(\mathrm{H}_{2} \mathrm{O}\right)$ & 5.82 \\
Soil pH $\left(0.01 \mathrm{M} \mathrm{CaCl}_{2}\right)$ & 5.34 \\
Organic matter $(\%)$ & 0.60 \\
Nitrogen $(\%)$ & 0.08 \\
Available P (mg/kg) & 5.20 \\
Exchangeable bases & \\
$\mathrm{K}^{+}(\mathrm{mmol} / \mathrm{kg})$ & 0.11 \\
$\mathrm{Ca}^{2+}(\mathrm{mmol} / \mathrm{kg})$ & 0.13 \\
$\mathrm{Mg}^{2+}(\mathrm{mmol} / \mathrm{kg})$ & 0.08 \\
$\mathrm{Na}^{2+}(\mathrm{mmol} / \mathrm{kg})$ & 0.11 \\
$\mathrm{Exchangeable} \mathrm{acidity}$ & \\
$\mathrm{H}^{+}(\mathrm{mmol} / \mathrm{kg})$ & 4.10 \\
$\mathrm{Al}^{3+}(\mathrm{mmol} / \mathrm{kg})$ & 1.30 \\
$\mathrm{Micronutrients}$ & \\
$\mathrm{Fe}(\mathrm{mg} / \mathrm{kg})$ & 8.30 \\
$\mathrm{Zn}(\mathrm{mg} / \mathrm{kg})$ & 3.83 \\
$\mathrm{Cu}(\mathrm{mg} / \mathrm{kg})$ & 2.20 \\
$\mathrm{Mn}(\mathrm{mg} / \mathrm{kg})$ & 1.85 \\
$\mathrm{Particle} \mathrm{size} \mathrm{analysis}_{\mathrm{Sand}(\%)}$ & \\
$\mathrm{Silt}(\%)$ & 79.30 \\
$\mathrm{Clay}(\%)$ & 14.70 \\
\hline
\end{tabular}

\section{Sources and processing of organic fertilizers used for the experiments}

Rice bran and wood ash were obtained from the large-scale processing unit of Federal College of Agriculture, Akure, which processed cassava tubers from 10,000 ha of cassava 
farm and paddy rice from 5000 hectares of rice plantation, while the poultry manure was also obtained from the 10,000 poultry birds in the livestock unit of the same institution. NPK 15-15-15 was purchased from Agricultural Development Programme, while the imported cabbage seeds (Benelli cultivar) were purchased from a certified seed company Agro-Farm Enterprises, Akure.

The organic materials were processed, wood ash was sieved with $2 \mathrm{~mm}$ sieve to remove pebbles, while rice bran was partially composted for four weeks to reduce $\mathrm{C} / \mathrm{N}$ ratio. Poultry manure was cured before application.

\section{Chemical analysis of the organic materials used}

Two grammes each of the processed forms of the organic materials was analysed. The $\mathrm{N}$ content was determined by the Kjeldahl method (Jackson 1964), while the determination of other nutrients such as $\mathrm{P}, \mathrm{K}, \mathrm{Ca}, \mathrm{Mg}$ was done using the wet digestion method based on $25-5-5 \mathrm{ml}$ of $\mathrm{HNO}_{3}-\mathrm{H}_{2} \mathrm{SO}_{4}-\mathrm{HClO}_{4}$ acids (AOAC 1970).

Table 3 shows the chemical analysis of the organic fertilizer used for the experiment. Wood ash had the highest values of $\mathrm{K}, \mathrm{Ca}$ and $\mathrm{Mg}$ followed by poultry manure and rice bran, respectively. Rice bran had the least values of $\mathrm{N}, \mathrm{P}, \mathrm{K}, \mathrm{Ca}$ and $\mathrm{Mg}$ and highest value of $\mathrm{C} / \mathrm{N}$ ratio. Poultry manure also had the highest value of $\mathrm{N}, \mathrm{P}$ and least $\mathrm{C} / \mathrm{N}$ ratio compared to others.

\section{Nursery establishment for cabbage seedlings}

Land clearing and packing of debris were carried out followed by shade construction made of erected bamboo poles and top covered with moderate number of palm fronds. Twelve nursery beds with a size of $1 \times 2 \mathrm{~m}^{2}$ each were prepared. The cabbage seeds were sown on March manually into rows spaced at $30 \mathrm{~cm}$ apart, irrigated twice a day (morning and evening) to ensure good germination and establishment. Germination of the seeds occurred 8 days after planting and seedlings were nursed for 2 weeks before transplanting. The nursery establishment is important because directly sown seeds will not germinate; hence, the erection of shade structure in the experiment was to control the prevailing temperature of the environment for seeds germination.

\section{Field experiment}

The experimental site was cleared, ploughed, harrowed and divided into different plots. Each plot size was $4 \times 4 \mathrm{~m}$ $\left(16 \mathrm{~m}^{2}\right)$. There were three organic fertilizers treatments, namely poultry manure, wood ash and rice bran, applied at $6 \mathrm{t} / \mathrm{ha}$ with a reference treatment NPK 15-15-15 fertilizer applied at $300 \mathrm{~kg} / \mathrm{ha}$ and a control treatment (no fertilizer). The experiment was arranged in a randomized complete block design and replicated three times. The choice of $6 \mathrm{t} /$ ha for wood ash, rice bran and poultry manure in the experiment was based on the works of Folorunso (1999) and Moyin-Jesu (2008) which carried out extensive research on determination of soil critical levels for N, P, K, $\mathrm{Ca}$ and $\mathrm{Mg}$ using organic amendments such as rice bran, cocoa husk, poultry manure, wood ash and pig manure for vegetables. They reported that application of these organic fertilizer materials at $6 \mathrm{t} / \mathrm{ha}$ was the best critical level for optimum yield of crop in the study area.

The organic amendments were incorporated into the soil using hand trowel one week before transplanting the seedlings. Twenty-day-old seedlings were transplanted to the experimental plots at a spacing of $50 \times 50 \mathrm{~cm}$. After transplanting, irrigation was done every mornings and evenings until the rain was steady to allow full establishment.

A low-cost shade made of erected bamboo poles and the top covered with palm fronds was constructed over the transplanted cabbage seedlings to reduce partially direct impact of sun radiations and enhanced the prevailing environment of the site to favour sustainable cabbage production.

Weeding was done manually 10 days after transplanting and continued at 2 weeks interval until harvesting. Cabbage seedlings were sprayed with Avesthrin (Cypermethrin $10 \mathrm{EC})$ at $10 \mathrm{ml} /$ litre of water at 3 weeks interval until 10 weeks after harvesting (WAT) to control leaf defoliating beetles and caterpillars. Growth parameters such as height, stem girth $(\mathrm{cm})$, leaf area $\left(\mathrm{cm}^{2}\right)$ and number of leaves were measured starting from 15 days after transplanting (DAT) until 80 days after transplanting. The leaf area was estimated using the non-destructive and accurate method of Jamal et al. (2009) based on determination of individual leaf area using a predictive equation constructed from leaf length $(L)$ and width $(W)$ and their combination.
Table 3 Chemical analysis of the organic fertilizer used for the experiment

\begin{tabular}{lccccccc}
\hline Treatments & $\mathrm{N}(\%)$ & $\mathrm{C}(\%)$ & $\mathrm{C} / \mathrm{N}$ & $\mathrm{P}(\mathrm{mg} / \mathrm{kg})$ & ${ }^{\circ} \mathrm{K}(\%)$ & $\mathrm{Ca}(\%)$ & $\mathrm{Mg}(\%)$ \\
\hline Poultry manure & 4.32 & 30.00 & 6.93 & 385.00 & 9.70 & 3.30 & 4.10 \\
Wood ash & 1.53 & 18.00 & 11.76 & 86.00 & 23.02 & 9.40 & 8.52 \\
Rice bran & 0.60 & 14.00 & 23.33 & 56.00 & 7.93 & 0.12 & 1.80 \\
\hline
\end{tabular}


Harvest of matured cabbage head started at 82 DAT and continued as they attain maturity in each experimental plot on treatment basis, and yield parameters such as cabbage head weight, cabbage head length and cabbage head girth were measured. In addition, it was observed that new shoots began to grow at the base of the harvested stem.

\section{Soil analysis after harvesting cabbage}

After harvesting, soil samples were taken from each plot using soil auger, bagged, air-dried and sieved for routine laboratory analysis. Soil pH, organic matter (O.M), N, P, $\mathrm{K}$, $\mathrm{Ca}$ and $\mathrm{Mg}$ were determined as described for the precropping soil analysis.

\section{Statistical analysis}

The average data of 2011 and 2012 cropping seasons on cabbage height, stem girth, leaf area, number of leaves, head weight, head girth and head length were analysed using ANOVA $F$ test, and the treatment means were compared using Duncan multiple range test at $5 \%$ level of significance (Gomez and Gomez (1984).

\section{Results}

\section{Effect of organic fertilizers on the growth parameters of cabbage between 15 and 80 days after transplanting (DAT)}

There were significant increases $(P<0.05)$ in the plant height, stem girth, number of leaves/plant and leaf area of cabbage under different organic fertilizer treatments compared to the control treatment (Table 4).

The highest values of cabbage plant height, stem girth, number of leaves and leaf area were obtained with poultry manure followed by NPK 15-15-15, wood ash and rice bran, respectively. The application of poultry manure treatment increased cabbage plant height, stem girth, leaf number/plant and leaf area by $17,19,10$ and $16 \%$ compared to NPK 15-15-15 fertilizer. The cabbage plant height, stem girth, number of leaves/plant and leaf area increased by 34, 26, 18 and $16 \%$ with application of poultry manure compared to rice bran. The least values of growth parameters in cabbage were also obtained under the control treatment.

\section{Effect of organic fertilizers on the head yield parameters of cabbage plant}

There were significant increases $(P<0.05)$ in the head yield parameters (head weight $\mathrm{t} / \mathrm{ha}$, head girth and head length) of cabbage under different organic fertilizers compared to the control treatment (Table 5).

The highest values of cabbage head yield parameters were obtained with poultry manure followed by wood ash and rice bran, respectively. When compared to NPK 15-1515 , application of poultry manure also increased cabbage head weight, head girth and head length by 17,18 and $8 \%$, respectively.

The application of poultry manure also increased cabbage head weight, head girth and head length by 23, 21 and $13 \%$ compared to the wood ash treatment, respectively. The least values of cabbage yield parameters were obtained under the control treatment.

\section{Soil chemical analysis after harvesting cabbage}

Significant increases $(P<0.05)$ occurred in the soil N, P, $\mathrm{K}, \mathrm{Ca}$ and $\mathrm{Mg}$ under different organic fertilizers compared to the control treatment (Table 6).

The soils which received NPK 15-15-15 fertilizer had the highest values of soil $\mathrm{N}, \mathrm{P}, \mathrm{K}$, and the lowest contents of O.M, $\mathrm{Ca}$ and $\mathrm{Mg}$. The highest values of soil organic matter (O.M) and moderate values of soil $\mathrm{P}, \mathrm{K}, \mathrm{Ca}$ and $\mathrm{Mg}$

Table 4 Effect of different organic fertilizers on the growth parameters of cabbage plants

\begin{tabular}{|c|c|c|c|c|c|c|c|c|c|c|c|c|}
\hline \multirow[t]{2}{*}{ Treatments } & \multicolumn{3}{|c|}{ Plant height $(\mathrm{cm})$} & \multicolumn{3}{|c|}{ Stem girth $(\mathrm{cm})$} & \multicolumn{3}{|c|}{ Leaf number } & \multicolumn{3}{|c|}{ Leaf area $\left(\mathrm{cm}^{2}\right)$} \\
\hline & 2011 & 2012 & Mean & 2011 & 2012 & Mean & 2011 & 2012 & Mean & 2011 & 2012 & Mean \\
\hline Control & $4.00 \mathrm{e}$ & $4.00 \mathrm{e}$ & $4.00 \mathrm{e}$ & $2.94 \mathrm{e}$ & $2.70 \mathrm{a}$ & $2.82 \mathrm{e}$ & $4.64 \mathrm{e}$ & $4.70 \mathrm{e}$ & $4.67 \mathrm{e}$ & $25.73 \mathrm{e}$ & $26.11 \mathrm{e}$ & $25.92 \mathrm{e}$ \\
\hline NPK 15-15-15 & $10.53 b$ & $10.75 b$ & $10.64 b$ & $5.66 \mathrm{~b}$ & $5.30 \mathrm{~b}$ & $5.48 \mathrm{~b}$ & $8.10 \mathrm{~b}$ & $8.16 b$ & $8.13 b$ & $74.90 \mathrm{~b}$ & $73.60 \mathrm{~b}$ & $74.75 b$ \\
\hline Rice bran & $8.50 \mathrm{~d}$ & $8.30 \mathrm{~d}$ & $8.40 \mathrm{~d}$ & $4.90 \mathrm{~d}$ & $5.18 \mathrm{c}$ & $5.04 d$ & $7.46 \mathrm{~d}$ & $7.48 \mathrm{~d}$ & $7.47 \mathrm{~d}$ & $37.36 \mathrm{~d}$ & $36.20 \mathrm{~d}$ & $36.73 d$ \\
\hline Wood ash & $8.70 \mathrm{c}$ & $8.90 \mathrm{c}$ & $8.80 \mathrm{c}$ & $5.04 \mathrm{c}$ & $5.14 d$ & $5.09 \mathrm{c}$ & $7.50 \mathrm{c}$ & $7.56 \mathrm{c}$ & $7.53 \mathrm{c}$ & $49.42 \mathrm{c}$ & $48.30 \mathrm{c}$ & $48.86 \mathrm{c}$ \\
\hline Poultry manure & $12.88 \mathrm{a}$ & $12.40 \mathrm{a}$ & $12.69 \mathrm{a}$ & $6.84 \mathrm{a}$ & $6.70 \mathrm{a}$ & $6.77 \mathrm{a}$ & $8.96 \mathrm{a}$ & $9.10 \mathrm{a}$ & $9.03 \mathrm{a}$ & $88.88 \mathrm{a}$ & $87.90 \mathrm{a}$ & $88.39 \mathrm{a}$ \\
\hline
\end{tabular}

Treatment means within each group followed by the same letters are not significantly different from each other using Duncan multiple range test at $5 \%$ level of significance 
Table 5 Cabbage head yield parameters under different organic fertilizer treatments

\begin{tabular}{|c|c|c|c|c|c|c|c|c|c|}
\hline \multirow[t]{2}{*}{ Treatments } & \multicolumn{3}{|c|}{ Head weight (t/ha) } & \multicolumn{3}{|c|}{ Head girth $(\mathrm{cm})$} & \multicolumn{3}{|c|}{ Head length $(\mathrm{cm})$} \\
\hline & 2011 & 2012 & Mean & 2011 & 2012 & Mean & 2011 & 2012 & Mean \\
\hline Control & $0.90 \mathrm{e}$ & $0.94 \mathrm{e}$ & $0.92 \mathrm{e}$ & $12.36 \mathrm{e}$ & $12.30 \mathrm{e}$ & $12.33 \mathrm{e}$ & $9.10 \mathrm{e}$ & $8.90 \mathrm{e}$ & $9.0 \mathrm{e}$ \\
\hline NPK 15-15-15 & $29.30 \mathrm{~b}$ & $28.90 \mathrm{~b}$ & $29.02 \mathrm{~b}$ & $31.80 \mathrm{~b}$ & $32.20 \mathrm{~b}$ & $32.00 \mathrm{~b}$ & $19.20 \mathrm{~b}$ & $18.30 \mathrm{~b}$ & $19.0 \mathrm{~b}$ \\
\hline Rice bran & $22.60 \mathrm{~d}$ & $22.20 \mathrm{~d}$ & $22.40 \mathrm{~d}$ & $24.87 \mathrm{~d}$ & $24.57 \mathrm{~d}$ & $24.67 \mathrm{~d}$ & $16.80 \mathrm{~d}$ & $17.20 \mathrm{~d}$ & $17.00 \mathrm{~d}$ \\
\hline Wood ash & $27.20 \mathrm{c}$ & $27.40 \mathrm{c}$ & $27.30 \mathrm{c}$ & $29.90 \mathrm{c}$ & $30.76 \mathrm{c}$ & $30.33 \mathrm{c}$ & $18.40 \mathrm{c}$ & $17.60 \mathrm{c}$ & $18.00 \mathrm{c}$ \\
\hline Poultry manure & $35.30 \mathrm{a}$ & $34.90 \mathrm{a}$ & $35.10 \mathrm{a}$ & $38.56 \mathrm{a}$ & $38.10 \mathrm{a}$ & $38.33 \mathrm{a}$ & $20.30 \mathrm{a}$ & $20.70 \mathrm{a}$ & $20.50 \mathrm{a}$ \\
\hline
\end{tabular}

Treatment means within each group followed by the same letters are not significantly different from each other using Duncan multiple range test at $5 \%$ level of significance

Table 6 Effect of different organic fertilizers on the soil chemical composition after harvesting cabbage

\begin{tabular}{|c|c|c|c|c|c|c|c|c|c|c|c|c|}
\hline \multirow[t]{2}{*}{ Treatment } & \multicolumn{3}{|c|}{ Soil pH } & \multicolumn{3}{|c|}{ O.M (\%) } & \multicolumn{3}{|l|}{$\mathrm{N}(\%)$} & \multicolumn{3}{|c|}{$\mathrm{P}(\mathrm{mg} / \mathrm{kg})$} \\
\hline & 2011 & 2012 & Mean & 2011 & 2012 & Mean & 2011 & 2012 & Mean & 2011 & 2012 & Mean \\
\hline Control & $5.30 \mathrm{~d}$ & $5.10 \mathrm{e}$ & $5.20 \mathrm{de}$ & $0.19 \mathrm{e}$ & $0.21 \mathrm{e}$ & $0.20 \mathrm{e}$ & $0.029 \mathrm{e}$ & $0.031 \mathrm{e}$ & $0.03 \mathrm{e}$ & $3.30 \mathrm{e}$ & $3.10 \mathrm{e}$ & $3.20 \mathrm{e}$ \\
\hline NPK 15-15-15 & $5.12 \mathrm{e}$ & $5.14 \mathrm{~d}$ & $5.13 \mathrm{e}$ & $0.27 \mathrm{~d}$ & $0.23 \mathrm{~d}$ & $0.25 \mathrm{de}$ & $0.39 \mathrm{a}$ & $0.35 \mathrm{a}$ & $0.37 \mathrm{a}$ & $28.40 \mathrm{a}$ & $28.80 \mathrm{a}$ & $28.60 \mathrm{a}$ \\
\hline Rice bran & $7.16 \mathrm{a}$ & $7.12 \mathrm{a}$ & $7.14 \mathrm{a}$ & $1.20 \mathrm{~b}$ & $1.22 \mathrm{~b}$ & $1.21 \mathrm{~b}$ & $0.25 \mathrm{c}$ & $0.27 \mathrm{c}$ & $0.26 \mathrm{c}$ & $15.90 \mathrm{c}$ & $15.52 \mathrm{c}$ & $15.71 \mathrm{c}$ \\
\hline Wood ash & $6.60 \mathrm{c}$ & $6.60 \mathrm{c}$ & $6.62 \mathrm{c}$ & $1.15 \mathrm{c}$ & $1.11 \mathrm{c}$ & $1.13 \mathrm{c}$ & $0.15 \mathrm{~d}$ & $0.19 \mathrm{~d}$ & $0.17 \mathrm{de}$ & $13.71 d$ & $13.53 \mathrm{~d}$ & $13.65 \mathrm{~d}$ \\
\hline Poultry manure & $6.92 b$ & $7.06 \mathrm{~b}$ & $6.99 \mathrm{~b}$ & $2.30 \mathrm{a}$ & $2.40 \mathrm{a}$ & $2.53 \mathrm{a}$ & $0.36 \mathrm{~b}$ & $0.34 b$ & $0.35 b$ & $25.55 b$ & $25.47 \mathrm{~b}$ & $25.51 b$ \\
\hline \multirow[t]{2}{*}{ Treatment } & \multicolumn{4}{|c|}{$\mathrm{Kmmol} / \mathrm{kg}$} & \multicolumn{4}{|c|}{$\mathrm{Ca}(\mathrm{mmol} / \mathrm{kg})$} & \multicolumn{4}{|c|}{$\mathrm{Mg}(\mathrm{mmol} / \mathrm{kg})$} \\
\hline & \multicolumn{2}{|c|}{2011} & 2012 & Mean & \multicolumn{2}{|c|}{2011} & 2012 & Mean & 201 & & 2012 & Mean \\
\hline Control & \multicolumn{2}{|c|}{$0.03 \mathrm{e}$} & $0.05 \mathrm{e}$ & $0.04 \mathrm{e}$ & \multicolumn{2}{|c|}{$0.06 \mathrm{~d}$} & $0.04 \mathrm{e}$ & $0.05 \mathrm{~d}$ & \multicolumn{2}{|c|}{$0.032 \mathrm{e}$} & $0.028 \mathrm{e}$ & $0.03 d$ \\
\hline NPK 15-15-15 & \multicolumn{2}{|c|}{$3.74 b$} & $6.68 \mathrm{a}$ & $3.71 \mathrm{a}$ & \multicolumn{2}{|c|}{$0.03 \mathrm{e}$} & $0.05 \mathrm{~d}$ & $0.04 \mathrm{e}$ & \multicolumn{2}{|c|}{$0.048 \mathrm{~d}$} & $0.052 \mathrm{~d}$ & $0.05 \mathrm{e}$ \\
\hline Rice bran & \multicolumn{2}{|c|}{$3.90 \mathrm{a}$} & $3.30 \mathrm{~b}$ & $3.10 \mathrm{~b}$ & \multicolumn{2}{|c|}{$1.54 \mathrm{a}$} & $1.52 \mathrm{a}$ & $1.53 \mathrm{c}$ & \multicolumn{2}{|c|}{$1.28 \mathrm{a}$} & $1.26 \mathrm{a}$ & $1.27 \mathrm{a}$ \\
\hline Wood ash & \multicolumn{2}{|c|}{$1.85 \mathrm{~d}$} & $1.53 \mathrm{~d}$ & $1.69 \mathrm{~d}$ & \multicolumn{2}{|c|}{$0.93 \mathrm{c}$} & $0.97 \mathrm{c}$ & $0.95 b$ & \multicolumn{2}{|c|}{$0.80 \mathrm{c}$} & $0.86 \mathrm{c}$ & $0.83 \mathrm{c}$ \\
\hline Poultry manure & \multicolumn{2}{|c|}{$2.45 \mathrm{c}$} & $2.65 \mathrm{c}$ & $2.40 \mathrm{c}$ & \multicolumn{2}{|c|}{$1.24 \mathrm{~b}$} & $1.22 \mathrm{~b}$ & $1.23 \mathrm{a}$ & \multicolumn{2}{|c|}{$1.13 \mathrm{~b}$} & $1.11 \mathrm{~b}$ & $1.12 \mathrm{~b}$ \\
\hline
\end{tabular}

Treatment means within each group followed by the same letters are not significantly different from each other using Duncan multiple range test at $5 \%$ level of significance

were obtained with the application of poultry manure. The application of wood ash resulted in the highest values of soil $\mathrm{pH}, \mathrm{Ca}$ and $\mathrm{Mg}$ compared to other treatments, while moderate values of soil $\mathrm{pH}, \mathrm{K}, \mathrm{Ca}$ and low $\% \mathrm{~N}$ were obtained with rice bran.

The soil N, P and K increased by 54, 53 and $55 \%$ with application of NPK 15-15-15 compared to rice bran treatment. Also, it had higher $\mathrm{K} / \mathrm{Ca}, \mathrm{K} / \mathrm{Mg}$ and $\mathrm{P} / \mathrm{Mg}$ ratio of 93:1, 74:1 and 572:1 $\mathrm{P} / \mathrm{Mg}$, respectively, compared to $2: 1 \mathrm{~K} / \mathrm{Ca}, 2: 1 \mathrm{~K} / \mathrm{Mg}$ and $16: 1 \mathrm{P} / \mathrm{Mg}$ in rice bran treatment.

The soil O.M, \% N and P increased by 49, 26 and $39 \%$, respectively, with application of poultry manure compared to wood ash. However, soil $\mathrm{pH}, \mathrm{K}, \mathrm{Ca}$ and $\mathrm{Mg}$ were increased by 3, 30, 20 and $12 \%$, respectively, under wood ash treatment compared to poultry manure. The least values of soil $\mathrm{pH}, \mathrm{N}, \mathrm{P}, \mathrm{K}, \mathrm{Ca}$ and $\mathrm{Mg}$ nutrients were obtained under control treatment.

\section{Discussion}

The least values of soil, growth and head yield parameters (number of leaf, leaf area, stem height, head length, head girth and head weight) obtained under the control treatment compared to other treatments could be as a result of initial low soil nutrients status that often characterize continuous cultivation of land without fertilizer application. This finding was supported by Mohammed and Solaiman (2012) who worked on the efficacy of fertilizers on the growth and yield of cabbage and reported that nutrients supply was an important input for realizing higher cabbage yield. Hence, the application of fertilizers, especially organic fertilizers, enhanced both soil and crop productivity in the tropics.

The best cabbage head weight, head length, head girth, number of leaf, leaf area, stem girth and plant height obtained from the application of poultry manure could be 
attributed to its balanced nutrient contents. The least value of $\mathrm{C} / \mathrm{N}$ ratio of poultry manure also encouraged faster decomposition and quick release of nutrients for crop uptake and higher head yield parameters. This observation was supported by Ijoyah and Sophie (2009) who reported that the application of poultry manure increased cabbage yield. However, the head yield of $35.10 \mathrm{t} / \mathrm{ha}$ of cabbage obtained in this experiment was higher than $25.76 \mathrm{t} / \mathrm{ha}$ reported by Ijoyah and Sophie (2009). The prior processing and stacking of poultry manure enhanced quick decomposition and reduction in $\mathrm{C} / \mathrm{N}$ ratio. This could be responsible for quick nutrient release and uptake by cabbage crop and hence higher cabbage head yield.

The increased soil $\mathrm{pH}$ obtained by the application of wood ash was attributed to its high $\mathrm{K}, \mathrm{Ca}$ and $\mathrm{Mg}$ contents which served as base saturation agents and consequently increased soil buffering capacity (Moyin-Jesu and Ogochukwu 2014). The soil pH influenced nutrient availability and uptake as reported by Obatolu (1995) that oil palm bunch ash, wood ash and cocoa pod husk improved soil K, $\mathrm{Ca}$ and $\mathrm{Mg}$ nutrients and corrected soil acidity in an Alfisol under cultivation of coffee and corn.

The lower values of cabbage growth and head yield parameters under rice bran treatment compared to wood ash and poultry manure could be adduced to the fact that higher $\mathrm{C} / \mathrm{N}$ ratio (23:3:1) of rice bran compared to poultry manure decelerated the residue decomposition rate and subsequently it had the least values of $\% \mathrm{~N}, \mathrm{P}, \mathrm{K}, \mathrm{Ca}$ and $\mathrm{Mg}$. The observation was supported by Moyin-Jesu (2007) who reported that the growth and yield performance of Okra were very low under the application of rice bran and sawdust. However, the processing of the organic fertilizer (rice bran) by composting was still responsible for reduction of $\mathrm{C} / \mathrm{N}$ ratio and the results would have been extremely different, if the rice bran was not processed because of its high $\mathrm{C} / \mathrm{N}$ ratio of 135:1. This was corroborated by Adebayo and Olayinka (1984) who used the unprocessed forms of oil palm bunch ash, sawdust and rice bran to grow maize; hence, prior processing of the organic fertilizers before application is important for good crop yield. Nevertheless, the inclusion of rice bran as source of fertilizer was important because it has been reported by Moyin-Jesu and Ojeniyi (2006) that rice bran, wood ash and spent grain were good in the reduction of soil bulk density and improved \% porosity which are good soil fertility indicators (i.e. soil physical properties).

The application of NPK 15-15-15 fertilizer significantly increased the cabbage head yield and growth parameters more than that of rice bran, and this could be traced to the supply of readily available nutrients from the NPK fertilizer to the plant. This observation agreed with that of Makinde (2013) who reported that an increase in the readily available nitrate from the NPK fertilizer unlike the organic manure which must be mineralized before being utilized by crops. Moyin-Jesu (2013a) also reported that nitrogen increased the vegetative and yield performance of garden egg crop.

However, the high content of nitrogen in the NPK fertilizer and its continuous use might be responsible for excessive vegetative growth of cabbage and subsequently delayed maturity. This could explain the lower values of cabbage head yield and growth parameters compared to the poultry manure treatment. Also, Tong et al. (1997) reported higher rate of nitrate nitrogen leaching which polluted underground water particularly with the continuous use of chemical fertilizers compared to the organic fertilizers. Furthermore, Moyin-Jesu (2012) reported that the high $\mathrm{K} / \mathrm{Ca}, \mathrm{K} / \mathrm{Mg}$ and $\mathrm{P} / \mathrm{Mg}$ ratios would cause nutrient imbalance and made availability of nutrients such as $\mathrm{K}, \mathrm{Ca}$, and $\mathrm{Mg}$ difficult for both immediate and subsequent cropping of cabbage.

\section{Conclusion}

This experiment showed that the use of the various organic fertilizers (poultry manure, wood ash and rice bran) applied at $6 \mathrm{t} / \mathrm{ha}$ increased the growth, head yield of cabbage and soil $\mathrm{N}, \mathrm{P}, \mathrm{K}, \mathrm{Ca}, \mathrm{Mg}, \mathrm{pH}$ and organic matter (O.M). It is recommended that poultry manure be applied at $6 \mathrm{t} / \mathrm{ha}$ for increased nutrient availability, growth and head yield of cabbage as well as enhancing sustainable cultivation of cabbage on commercial basis. The use of poultry manure would replace the application of large quantity of NPK 15-15-15 fertilizer.

The recommendation is important because the inorganic fertilizers are becoming very expensive to be purchased by small-scale and commercial farmers of cabbage. In addition, these organic fertilizers appear to have beneficial secondary effects on soil properties and ensuring environmental sustainability.

Open Access This article is distributed under the terms of the Creative Commons Attribution 4.0 International License (http://crea tivecommons.org/licenses/by/4.0/), which permits unrestricted use, distribution, and reproduction in any medium, provided you give appropriate credit to the original author(s) and the source, provide a link to the Creative Commons license, and indicate if changes were made.

\section{References}

Adebayo A, Olayinka A (1984) The effect of methods of application of sawdust on plant growth, nutrient uptake and soil chemical properties. Ife J Agric 2(1):36-44

Afshar RK, Chaichi MR, Assareh MH, Hashemi M, Liaghat A (2014) Interactive effect of deficit irrigation and soil organic 
amendments on seed yield and flavonolignan production of milk thistle (Silybum marianum L, Gaertn). Ind Crop Prod 58:166-172

Agboola AA, Corey RB (1973) Soil testing N, P, K for maize in the soils derived from metamorphic and igneous rocks of Western State of Nigeria. J West Afr Sci. Assoc 17:93-100

AOAC (1970) Official method of analysis 12th eds. Association of official Analytical Chemists Arlington, VA

Awodun MA (2007) Effect of sawdust ash on nutrient status, growth and yieldof Cowpea (Vigna unguiculata L. Walp). Asian J Agric Res 1:92-96. doi:10.3923/ajar

Bouycous H (1951) Mechanical analysis of soil using hydrometer method analytical chem. Acta 22:32-34

Crockford L, Nowel P (1956) Laboratory manual of physical chemistry. Exp 31 and 32. John Wiley and Sons, New York

Folorunso OO (1999) Use of plant residues for improving soil fertility and yield of Okra (Abelmuschus esculentum L Moench) and Amaranthus (Amaranthus viridis L). PhD thesis, School of Agriculture and Agriculture Technology, Federal University of Technology, Akure, Nigeria: 45-50

Folorunso OO, Agboola AA, Adeoye GO (2000) Evaluation of three fertilizer models for $\mathrm{P}$ and $\mathrm{K}$ recommendation in maize (Zea Mays L). J Tech Educ 2:237-253

Gomez KA, Gomez AA (1984) Statistical procedures for agricultural research, 2nd edn. John Wiley and Sons, New York

Hague KMF (2006) Yield and nutritional quality of cabbage as affected by nitrogen and phosphorous fertilization. Bangladeshi $\mathrm{J}$ Sci Med Res 41:41-46

Ijoyah MO, Sophie VL (2009) Effect of different levels of decomposed poultry manure on the yield of cabbage (Brassica Oleraceae L). Agro Sci J Trop Agric Food Environ Ext $8(1): 20-23$

Jackson ML (1958) Soil chemical analysis. N.J Prentice Hall, Englewood Cliffs, pp 57-69

Jackson ML (1964) Soil chemical analysis. N.J Prentice Hall, Englewood Cliffs, pp 86-92

Jamal Ali Olfati, Peyvast G, Samavi M, Salehi M, Mahdipour M, Nosratie-Rad Z (2009) Comparison of leaf area estimation from linear measurement of Red cabbage. Int J Veg Sci 15:185-192. doi:10.1080/19315260802770

John J (1997) Drug and food interaction. J Nutr Fla 9(2):7-9

Kwari JD, Bababe B, Shehu HE (1991) Effect of cow dung on CEC and accumulation of mineral nitrogen, phosphorus and sulphur in soils of Borno state. In: Ojeniyi S.O (eds). Proceedings 19th Annual conference of Soil Sci Soc, Nigeria, Nov 17-21, 1991. University of Maiduguri: 154-158

Makinde A (2013) Effect of inorganic fertilizer on the growth and nutrient composition of moringa. J Emerg Trends Eng Appl Sci (JETEAS) 4(2):34-343

Moamogwe M (1995) Adaptation trial of introduced cabbage cultivars ARP training reports between 1993-1995. AVRDC Afr Reg Program Arusha Tanzan 4(1):27-29

Mohammed RH, Solaiman AHM (2012) Efficacy of organic and inorganic fertilizers on the growth of cabbage (Brassica Oleraceae L). Int J Agric Crop Sci 4(3):128-138. ISBN $2227-670 X$

Moyin-Jesu EI (2007) Use of plant residues for improving soil fertility, pod nutrients, root growth and pod weight of Okra (Abelmuschus esculentum L). Bioresour Technol 98(2007):2057-2064

Moyin-Jesu EI (2008) Determination of soil nutrient levels for maximum yield of Okra using sole and amended plant residues. J Trop Agric Sci 31(2):233-245 (Malaysia)
Moyin-Jesu EI (2012) Simple and blended organic fertilizers improve soil fertility of degraded nursery soil for production of Kolanut (Cola acuminate) seedlings in Nigeria. In: Tech Open Publishers. Chapter book 15. EdsJoann K. Whalen. ISBN: 978-953-307945-5. p 209-306. http://www.intechweb.org

Moyin-Jesu EI (2013a) Evaluation of modified neem leaf and wood ash extracts on the soil fertility improvement on growth and yield of garden egg plant. (Solanium melongena L.) Colombia International Publishing. Am J Agric Sci Tech 1(3):77-76. doi:10.776/ajast.2013.1007

Moyin-Jesu EI, Odewande A (2013) Comparative evaluation of different tillage practices and method of planting on soil properties, growth and head yield of cabbage. Am J Res Commun 1:1-20

Moyin-Jesu EI, Ogochukwu AI (2014) Comparative evaluation of different organic fertilizer effects on soil fertility, leaf chemical composition and growth performance of coconut (Cocos nucifera) seedlings. Int J Plant Soil Sci 3(6):737-750. doi:10. 9734/IJPSS/2014/4338

Moyin-Jesu EI, Ojeniyi SO (2006) Effects of sole and amended plant residues on soil nutrient contents and yield of Okra (Abelimoschus esculentum L). Discov Innov J 18(4):318-326

Murphy J, Riley JP (1962) A modified single solution method for determination of phosphate in natural waters. Anal Chem Acta 27:31-36

Obatolu CR (1995) Nutrient balance sheet of Alfisol grown to coffee and maize using organic fertilizers. In: Agboola AA (eds) Proceedings 3rd Annual Conference of All African Soil Sci Society, University of Ibadan, Ibadan, August 20-23,1995: 250-256

Obi ME, Ofonduro CO (1997) The effects of soil amendments on soil physical properties of a severely degraded sandy loam soil in south Eastern Nigeria. Usman Danfodio University, Sokoto, pp 30-35 (March 2-7)

Ojeniyi SO, Oso OP, Arotolu AA (2001) Response of vegetables to wood ash fertilizer. In: Obigbesan OO (ed) Proceedings 30th annual conference of agric society of nigeria. University of Agriculture, Abeokuta, pp 147-150

Sobulo RA, Osiname OA (1981) Soils and fertilizer use in Western Nigeria. Tech Bull no. 11. Institute of Agricultural Research and Training, University of Ife, Nigeria

Soil Survey Staff (1999) Soil taxonomy. A basic system for soil classification for making and interpreting soil surveys agric handbook no. 436. USDA, Washington DC

Solomon MG, Ogeh JS (1995) Use of leguminous plants and rice husk as fertilizer materials. In: Agboola AA (eds). Proceedings 3rd All African Soil Science Conference August 20-23, 1995, University of Ibadan. 327-333

Tindall M (2000) Mineral and organic fertilizing in cabbage and their residual effect for commercial cultivation on yield and quality performance of cabbage. Hort Brass 6:15-20

Tong Y, Ove E, Dianquing L, Harald G (1997) Effect of organic manure and chemical fertilizers on nitrogen uptake and nitrate leaching in a Eum orthic anthrosols profile. Nutr Cycl Agroecosyst 48(3):225-229

Walkley A, Black IA (1934) An examination of degtajroff method for determining soil organic acid filtration method. Soil Sci 37:29-38 